\title{
The Integrated Relationship among Organizational Learning, TQM and Firm's Business Performance: A Structural Equation Modeling Approach
}

\author{
Chen-Ying Lee ${ }^{1} \&$ Hsu-Hua Lee ${ }^{2}$ \\ ${ }^{1}$ Department of Risk Management and Insurance, Shih Chien University, Taiwan, Republic of China \\ ${ }^{2}$ Graduate Institute of Management Sciences, Tamkang University, Taiwan, Republic of China \\ Correspondence: Chen-Ying Lee, Department of Risk Management and Insurance, Shih Chien University, \\ Taiwan, Republic of China. E-mail: chenying0207@yahoo.com.tw
}

Received: February 14, 2015

Accepted: March 17, 2015

Online Published: April 25, 2015

doi:10.5539/ibr.v8n5p43

URL: http://dx.doi.org/10.5539/ibr.v8n5p43

\begin{abstract}
The methodology of the organizational learning and total quality management (TQM) in the industry is becoming crucial, but there are few empirical studies to investigate the relationship between organizational learning and TQM on business performance in non-life insurance industry. The purpose of this paper is to understand the integrated relationship between organizational learning and TQM as two sources of sustainable competitive advantage. The paper proposes several hypotheses related to the relationship among organizational learning, TQM and business performance. A survey method is used to collect empirical data from non-life insurance companies in Taiwan. In this study, 414 effective questionnaires are analyzed and structural equation modeling (SEM) is used to verify the research framework and hypotheses. The empirical findings indicate that: (1) Organizational learning has significant and positive effects on TQM, (2) Both organizational learning and TQM have significant and positive effects on business performance, (3) TQM fosters business performance and play a mediating role between organizational learning and business performance. Therefore, the study demonstrates that the model can integrate organizational learning and TQM practices and enhance business excellence in financial service organizations, and also extend the prior research and contribute to the existing body of literature.
\end{abstract}

Keywords: organizational learning, total quality management, integrated relationship, business performance, structural equation modeling

\section{Introduction}

At the end of 1980s amid the trends of financial liberalization, internationalization and economy development, the insurance industries have vigorous growth year after year. According to Taiwan Insurance Institute (TII) reports, the combined market share of top five non-life insurers rose from $54.4 \%$ in 2006 to $61.0 \%$ in 2013 as a result of merger and acquisition among insurers, indicating a rising trend in market concentration with high competition. The non-life insurance industries sell intangible products and provide "risk management" as well as "service value". Therefore, it can be accepted that the blue ocean strategy for insurance business, by providing customers with diversified expertise and quality services, has become a crucial topic in present non-life insurance industry. Recently, as information technology advances and industrial competition is no longer resource-based, the accumulation and use of knowledge within the organization are the most important intellectual assets to create value (Senge, 1990). Organizational learning prioritizes the creation and acquisition of new knowledge, and emphasizes the role of people in the creation and utilization of knowledge (Denton, 1998). Meso et al. (2002) argue that organizational learning has a strategic significance for the sustainability competitive position of the firm. The non-life insurance industry is a knowledge-based industry with its main products of insurance contracts, which are commitments supported by professional knowledge and service value. Thus, there is more need to draw on the organization's ability to learn and make non-life insurance companies to stay competitive in a rapidly changing environment in order to enhance firm's business performance.

Juran (1993) argued that competitive advantages could be obtained by the quality or service of products, and quality control has gradually become the critical competitive factor in the global market. As a result, total quality 
management (TQM) has been widely accepted as the effective management tool to provide stable business operation, growth and success for enterprises (Issac et al., 2004). Numerous past literatures have confirmed that TQM increased customer satisfaction (Lee et al., 2010) and improved organizational performance (Irani et al., 2004; Ebrahimi \& Sadeghi, 2013; Sadikoglu \& Olcay, 2014), such as firm's quality performance, leading to an improved financial and market performance (Kaynak, 2003). Moreover, the organizations committing scarce resources to the quality model process can obtain synergistic benefits in other areas, especially organizational learning (Leonard \& McAdam, 2003).

In summary, the purpose of this research is to analyze the integrated relationship among organizational learning, TQM and firm's business performance. This paper extends the prior research and contributes to the existing body of literature. First; the empirical results support the relationships between organizational learning, TQM practices, and firm's business performance on financial service industry. Second, this study examines TQM to foster business performance and plays mediating role between organizational learning and business performance. Third, this study tests an integrated model to explain the relationships among organizational learning, TQM, and business performance through an empirical examination in the non-life insurance industry in order to provide a recommendation to strength the competitive advantage, and the results can be applied to other financial service industries.

\section{Literature Review and Hypotheses}

\subsection{Relationship between Organizational Learning, TQM, and Business Performance}

Barrow (1993) argues that TQM and organizational learning are inextricably connected for the reason that learning is an intended effect of TQM and that process improvement and organizational learning are operating in a concurrent integrated way. Chiles and Choi (2000) further confirm that organizational learning is linked to quality management through customer focus, teamwork, adjustment to turbulent environment and continuous improvement. Moreno et al. (2009) use empirical data gathered from 202 quality managers to support and find that there is a strong connection between organizational learning and quality management. Li et al. (2011) also find that organizational learning (both explorative and exploitation learning) positively affect product quality. In addition, Koçoğlu et al. (2011) reveal that organizational learning constructs have positive influence on TQM. Therefore, organizational learning can play the role of facilitator of TQM environment. Based on the preceding discussion, we propose the following hypothesis:

H1: Organizational learning will positively effect on TQM in non-life insurance companies.

The firms with effective TQM implementation can accomplish the internal benefits such as improving quality, enhancing productivity, or realizing better operating income (Hendricks \& Singhal, 1997; Prajogo \& Brown, 2004; Corbett et al., 2005). Some studies have suggested that TQM-adopting firms enjoy a competitive advantage over non-TQM (Powell 1995, Brah et al., 2000). Furthermore, numerous empirical studies, which attempt to examine the impact of TQM, support the proposition that a continuous commitment to TQM implementation has a significant positive effect on superior firm performance, as evidenced in the case of service firms (Agus, 2004), small and medium enterprises (Ahmad et al., 2014; Wali \& Boujelbene, 2010; Salaheldin, 2009) and European companies (Boulter et al., 2013). Based on the preceding discussion, we propose the following hypothesis:

H2: TQM will positively effect on firm's business performance in non-life insurance companies.

Organizational learning is valuable to firm's customers because it focuses on understanding and effectively satisfying their expressed and latent needs through new products, services and ways of running the business (Slater \& Narver, 1995; Lukas et al., 1996). This shall directly lead to superior outcomes, such as greater success of new products, superior customer retention, higher customer-oriented quality, and ultimately superior growth and /or profitability (Lukas et al., 1996; Hurley \& Hult, 1998; Bontis et al., 2002). Yang et al. (2007) also provide a more thorough assessment of the link between organizational learning and organizational performance, and demonstrate that organizational learning can influence firm's performance. In addition, Santo-Vijande et al. (2012) confirm the expected relationships and reveal organizational learning as an important instrument in modern markets to provide customer value and improve organizational performance by means of efficiently competitive strategy design and flexible adaptation to rapid market evolution. Noruzy et al.(2013) show that organizational learning and organizational innovation directly influenced organizational performance among manufacturing firms. Thus, based on the preceding discussion, the following hypothesis is suggested:

H3: Organizational learning will positively effect on firm's business performance in non-life insurance companies.

\subsection{Organizational Learning and Business Performance: The Mediating Roles of TQM}

TQM is easy to create organizational learning environment, on the other hand, organizational learning by 
changing the environment, continuous improvement can absorb new ideas and innovation to create competitive advantage (Sohal \& Morrison, 1995). Therefore, through the successful implementation of the TQM, the organization can develop the knowledge transfer to the promotion of a culture of knowledge sharing and cross-functional teams will contribute to organizational learning (O’Dell \& Grayson, 1998). Enhancing competitiveness through TQM has become an increasingly important challenge for learning in the organizations. Consequently organizational learning must be mentioned as a key issue, especially for organizations seeking to make progress towards TQM (Martinez-Costa \& Jimenez-Jimenez, 2009). Hung et al. (2011) show that TQM has a significant and positive effect on innovation performance and organizational learning, and partially mediates such effect. Lam et al. (2011) also suggested the managers of the service firms who intend to achieve organizational success through the implementation of TQM practices that support their firm's learning orientation and enhance their market performance. Another study conducted by Koçoğlu et al. (2011) focus on developing a platform form through which organizational learning shapes the strategic management of the organizations using the role of innovation and TQM for the aim of achieving improved firm performance. Moreover, Honarpour and Asadi (2012) indicate that the nature of relationship TQM and organizational learning is synergetic, thereby meaning that the reciprocal causation between TQM and organizational learning have a synergetic effects. Based on the preceding discussion, the following hypothesis is suggested:

H4: TQM mediates the relationship between organizational learning and firm's business performance in non-life insurance companies.

\subsection{Research Model}

Based on the literature review and theory development, a research model is developed in order to investigate the relationship among the promotion of organizational learning, TQM, and business performance in the non-life insurance industries. The concept of the proposed research framework is illustrated in Figure 1. By using structural equation modeling (SEM), this study conducts further empirical study and analysis of the proposed hypothesis. This study first explores the impact of promotion of organizational learning and TQM on business performance in the case of non-life industries. Second, we will investigate the mediation effects of TQM on organizational learning to business performance in non-life insurance industries.

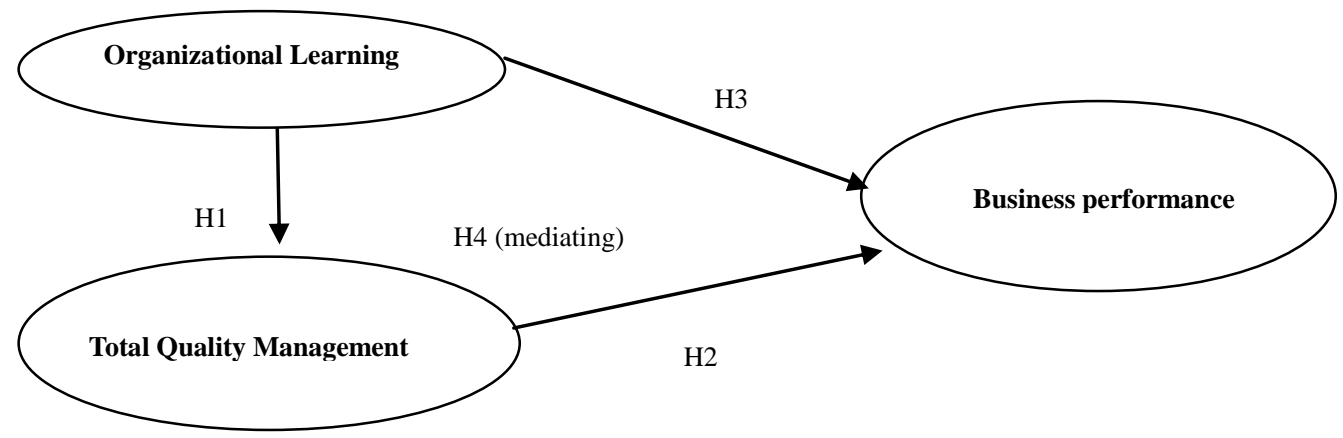

Figure 1. The research framework

\section{Methodology}

\subsection{Sample and Data Collection}

This study targets the non-life insurance industry in Taiwan. Judgment sampling is used to determine the sampling objects from The Non-life Insurance Association of the R.O.C. (2013). The data of this research is from the survey of 9 non-life insurance companies. Subjects are the employees in non-life insurance companies, including both staffs and managers, with more than one year of experience. The nine companies were Fubon, Cathay, ShinKong, Ming Tai, Tokio Marine Newa ,Union, Taian, Chug Kuo and South China respectively, (ratio of employees to the entire Non-life Insurance Industry) account for $77.1 \%$ of all non-life insurance employment in 2013. Hence, the overall sample is representative and can relatively reflect the actual situation of the non-life insurance companies. A pilot study is conducted with a small size of 30, to clarify the overall structure of questionnaire. The respondents provide the comments on clarity of some items and confirm the validity of items in the questionnaire. Following the pilot test, the main survey is administered. A total 550 questionnaires are distributed in the main survey, and 434 questionnaires were collected. Among those, 20 participants did not respond to all questions, so a total of 414 questionnaires were used in the final sample, the valid questionnaires account for an effective response rate of 
75.3\%. A description of sample is shown in Table 1. It is conspicuous that women account for $51.21 \%$ of total sample. The highest educational attainment is primarily university graduate $(49.03 \%)$. The seniority of the surveyed employees between 1 and 5 years accounts for $45.65 \%$.

Table 1. Demographic information on respondents $(\mathrm{N}=414)$

\begin{tabular}{llcc}
\hline Variable & Category & Sample number & Percentage $(\%)$ \\
\hline \multirow{2}{*}{ Gender } & Male & 202 & 48.79 \\
& Female & 212 & 51.21 \\
& Less than 25 years & 39 & 9.42 \\
Age & $25-35$ years & 197 & 47.58 \\
& $36-45$ years & 123 & 29.71 \\
& $46-55$ years & 47 & 11.35 \\
Education & Over 56 years & 8 & 1.94 \\
& Senior high school & 46 & 11.11 \\
& College & 108 & 26.09 \\
Seniority & University & 203 & 49.03 \\
& Graduate school & 57 & 13.77 \\
& $1-5$ & 189 & 45.65 \\
Position & $6-15$ & 170 & 41.06 \\
& 16 or more & 55 & 13.29 \\
\hline
\end{tabular}

\subsection{Questionnaire Design and Measures of Constructs}

The questionnaires are designed with single choice items, and can be divided into four parts. The first part contains 15 items on the subject's views about the implementation of organizational learning activities. This study is according to the characteristics of non-life insurance and through a comprehensive review literature, then organizational learning will be divided into three constructs including learning orientation (Hult \& Ferrel, 1997), information orientation (Huber, 1991; Tippins \& Sohi, 2003) and team orientation (Hult et al., 2002). The second part contains 19 items on the subject's cognition of the implementation of TQM by the non-life insurance company. This study is based on the characteristics of the non-life insurance companies and through a comprehensive review of the TQM literature, with four constructs of TQM practices, named customer focus (Oakland, 2005; Fotopoulos \& Psomas, 2010; Phan et al., 2011), continuous improvement (Tsang \& Anltony, 2001; Wang et al., 2012 ), process management (Brah et al., 2000; Sila \& Ebrahimpour, 2005; Samat et al., 2006) and service culture (Sureshchander et al., 2001; Selvaraj, 2009) to represent the core of TQM practices which are found to be useful and relevant to the service industries (Brah et al., 2000; Tsang \& Antony, 2001). The third part contains 10 items on the impact of the implementation of organizational learning and TQM on the firm's business performance, which according to Hao et al. (2012) divide into two constructs including financial performance (e.g., Premium revenues, profit after tax, cost improvement) and non-financial performance (e.g., market share, customer satisfaction, employee productivity). Instead of directly asking respondents to report objectives measures of their firm's financial and non-financial performance in terms of profit rates, market share, premium revenue, cost improvement, customer satisfaction and employee productivity in this study, a more indirect approach for collecting the data was utilized to avoid the omission of sensitive performance data. Similar indirect measures of firm performance have been used in prior strategy research when financial statement data was either unavailable or when they did not allow for accurate comparisons among the firms (Spanos \& Lioukas, 2001; Tippins \& Sohi, 2003). Likewise, the research has shown that perceived measures of performance could be a reasonable substitute for objective measures of performance (Dess \& Robinson, 1984) and had a significant correlation with objective measures of financial performance (Delaney \& Huselid, 1996). The fourth part contains 5 items on the basic personal information of the subject including the gender, age, educational level, seniority and position. Questionnaires are designed using a five-point Likert scale to facilitate measurement. Scores of 5, 4, 3, 2 and 1 are used to represent the answers to mean 'strongly agree', 'agree', 'no comment', 
'disagree', 'strongly disagree', respectively. The operational definition of organizational learning, TQM, and business performance is shown in Table 2 .

Table 2. Operational definitions and measurement items for the research variables

\begin{tabular}{|c|c|c|}
\hline Dimensions of organizational learning & Operational definition & Sources \\
\hline Learning orientation & $\begin{array}{l}\text { Organization-wide activity of creating and using } \\
\text { knowledge to enhance competitive advantage. }\end{array}$ & Calantone et al. (2002) \\
\hline Information orientation & $\begin{array}{l}\text { Integration of information including information } \\
\text { acquisition and information dissemination }\end{array}$ & Huber,(1991); Tippins and Sohi,( 2003) \\
\hline Team orientation & $\begin{array}{l}\text { Organizational members focused on sharing, thinking } \\
\text { together to solve problem and charting the future } \\
\text { operations of organization }\end{array}$ & Senge (1990) \\
\hline \multicolumn{3}{|l|}{ Dimensions of TQM } \\
\hline Customer focus & $\begin{array}{l}\text { Quality goals started the understanding of customer } \\
\text { needs and ended when those needs were satisfied. }\end{array}$ & Phan et al.(2011); Oakland(2005) \\
\hline Continuous improvement & $\begin{array}{l}\text { Employees working in teams, having open access to } \\
\text { management and corrective action program striving for } \\
\text { continuous improvement. }\end{array}$ & $\begin{array}{l}\text { Wiengarten et al. (2013); Slia and } \\
\text { Ebrahimpour (2005) }\end{array}$ \\
\hline Process management & $\begin{array}{l}\text { Reduce process variation by building quality into } \\
\text { operational process }\end{array}$ & Flynn et al.(1995) \\
\hline Service culture & $\begin{array}{l}\text { An organizational strategy that motivates the employees } \\
\text { to have a service orientation in whatever they do. }\end{array}$ & Sureshchander et al. (2001) \\
\hline \multicolumn{3}{|l|}{ Dimensions of business performance } \\
\hline Financial performance & Premium revenues, profit after tax, cost improvement & $\begin{array}{l}\text { Venkatraman and Ramanujam (1986); } \\
\text { Hao et al.(2012). }\end{array}$ \\
\hline Non-financial performance & $\begin{array}{l}\text { Market share, customer satisfaction, employee } \\
\text { productivity }\end{array}$ & $\begin{array}{l}\text { Venkatraman and Ramanujam (1986); } \\
\text { Hao et al.(2012). }\end{array}$ \\
\hline
\end{tabular}

\subsection{Reliability and Validity}

This study can apply Cronbach's á to verify the consistency of items. According to Nunnally's (1978) point of view, a score more than 0.7 is considered reliable. Since the Cronbach's á of this study's organizational learning, TQM, and business performance dimensions are all more than 0.7 , these are consistently reliable. Regarding the validity, the contents of this study's questionnaire are based on the relevant theories and referred to related literatures' questionnaire contents and include the opinions of scholars. Thus, this study has a considerable degree of content validity. To test the construct validity of the questionnaire, factor analysis is performed on each construct. The Kaiser-Mayer-Olkin (KMO) measure of sampling adequacy test (Kaiser, 1974) and Bartlett's (1950) Sphericity test are carried out to evaluate the adequacy of each item. Hair et al. (1998) suggest that, when the KMO value is larger than 0.6 and the p-value of the Bartlett's Sphericity test is closer to 0 , it means that the item is adequate for factor analysis. The results show that all the items have a measure above 0.9, indicating the partial correlation among items is low and a high degree of collinearity is absent. Baerlett's test also shows that all the measures reach the level of significance $(\mathrm{p}<0.000)$, indicating that a common factor is present. Therefore, the designed scale is appropriate for factor analysis.

The method of principle component and Varimax are used to extract 3 constructs of organizational learning, 4 of TQM, and 2 of business performance. In addition, according to Chang (2008), whether the questionnaire has validity, it can be judged by the factor loading of the factor analysis. In order to obtain both good reliability and validity, the questions with factor loading less than 0.5 are deleted through exploratory factor analysis. Hence, this study modifies the original questionnaire and reviews the validity of the modified questionnaire. According to the above standard, in TQM dimension, five items should be removed. The modified TQM dimension contains 14 items, and no item is removed from the other two dimensions. The reliability and validity test are shown in Table 3. 
Table 3. Reliability and validity test $(\mathrm{N}=414)$

\begin{tabular}{|c|c|c|c|c|}
\hline Construct & Variables & Cumulative $\%$ of Explained variance & Number of items & Cronbach’s á \\
\hline \multirow{3}{*}{ Organizational learning } & Learning orientation & $58.06 \%$ & 4 & 0.835 \\
\hline & Information orientation & $62.00 \%$ & 6 & 0.922 \\
\hline & Team orientation & $65.08 \%$ & 5 & 0.906 \\
\hline \multicolumn{5}{|c|}{ KMO Value $=0.965$, Bartlett Bartlett's test $=4571.613, \mathrm{Sig}=0.000$, Factor loading $0.55-0.74$} \\
\hline \multirow{4}{*}{ Total quality management } & Continuous improvement & $49.16 \%$ & 4 & 0.835 \\
\hline & Customer focus & $57.42 \%$ & 3 & 0.877 \\
\hline & Service culture & $61.65 \%$ & 4 & 0.882 \\
\hline & Process management & $64.28 \%$ & 3 & 0.816 \\
\hline \multicolumn{5}{|c|}{ KMO Value $=0.926$, Bartlett Bartlett's test $=3200.562, \mathrm{Sig}=0.000$, Factor loading $0.53-0.84$} \\
\hline \multirow{2}{*}{ Business performance } & Financial performance & $59.12 \%$ & 5 & 0.918 \\
\hline & Non-financial Performance & $64.12 \%$ & 5 & 0.841 \\
\hline KMO Value $=0.935$, Bartle & lett's test $=2753.367, \mathrm{Sig}=0.00$ & Factor loading $0.53-0.77$ & & \\
\hline
\end{tabular}

\subsection{Common Method Various (CMV) test}

As this study utilized one self-report survey to collect data on all of variables, common method bias may be resent. Following Podsakoff et al. (2003), the Harman's one-factor test is used. A factor analysis of the dependent and independent variables did not yield a single-factor structure that would account for majority of the variance, thus it is not a problem in the samples.

\section{Empirical Analysis and Results}

\subsection{Structural Equation Model (SEM)}

The proposed four hypotheses are tested simultaneously using SEM. If the model does not fit data well, the initial proposed deleting insignificant paths will modify model and is then tested again. This process ends when the model fits well after the evaluation by a two-step procedure. The first step is to examine the significance path and measurement coefficients. The second step is to examine the whole model fit by using multiple criteria, as recommended by previous scholars (Hu \& Bentler, 1999; Schumacker \& Lomax, 2004; Hair et al., 2006). Since $\chi^{2}$ is sensitive to sample size, due to our large sample size, an alterative of normed chi-square ( $\left.\chi^{2} / \mathrm{df}\right)$ is used to assess the model fit (Bagozzi \& Yi, 1988). Bollen (1989) noted that values of the $(\chi 2 / \mathrm{df})<5$ have been recommended as indicating reasonable fit. Using this approach, the value of $(\chi 2 / \mathrm{df})$ is $4.503,<5$ and therefore within recommended tolerance. After confirming the total measurement model, the structural model is estimated, producing the following statistics: $\mathrm{GFI}=0.942$, $\mathrm{AGFI}=0.882$, NFI $=0.959, \mathrm{CFI}=0.942, \mathrm{IFI}=0.967, \mathrm{PGFI}=0.461$, $\mathrm{PNFI}=0.586, \mathrm{RMR}=0.023$, RMSEA $=0.103$. We conclude that the overall fit of structural model is acceptable. The index fit of the model is shown in Table 4.

Table 4. Results of the overall structure model fit

\begin{tabular}{lcc}
\hline Indices & Recommended value & Indices value \\
\hline$\chi 2 /$ df & $<5$ & 4.503 \\
Good-of -fit index (GFI) & $\geqq 0.9$ & 0.942 \\
Adjusted good-of-fit index(AGFI) & $\geqq 0.9$ & 0.882 \\
Normed fit index(NFI) & $\geqq 0.9$ & 0.959 \\
Comparative fit index (CFI) & $\geqq 0.9$ & 0.942 \\
Incremental fit index(IFI) & $\geqq 0.9$ & 0.967 \\
Parsimonious goodness of fit index(PGFI) & $\geqq 0.5$ & 0.461 \\
Parsimonious normed fit index (PNFI) & $\leqq 0.5$ & 0.586 \\
Root mean residual (RMR) & $\leqq 0.1$ & 0.023 \\
Root mean square error of approximation(RMSEA) & & 0.103 \\
\hline
\end{tabular}




\subsection{Test of the Hypotheses}

An examination of the present study is shown in Table 5. The estimated results using the maximum likelihood estimation as well as the model path diagram are shown in Figure 2. A further evaluation in the structural model indicates that organizational learning directly affects TQM $(\hat{a}=0.882 ; \mathrm{p}<0.001)$ and TQM directly affects business performance $(\hat{a}=0.223, \mathrm{p}<0.05)$. The organizational learning also directly affects business performance $(\hat{a}=0.509$, $\mathrm{p}<0.001)$. These analytical results indicate that the introducing organizational learning promotes TQM and business performance. In addition, the promotion of TQM can enhance business performance. These analytical results of the path show the Hypotheses 1-3 are supported. Furthermore, the indirect effect of the business performance of an organization from organizational learning through TQM is $0.197(0.882 \times 0.223)$. Therefore, the total effect on business performance by the mediating effect of organizational learning through TQM is 0.706 (0.509+0.197). Furthermore, according to Ullman (2007) direct and indirect effects analysis, the indirect effect is only $27.9 \%$ of the total effect, and therefore TQM has a statistically significant partial mediating effect on the model.The result shows that Hypotheses 4 is supported. Finally, the relationship between the various aspects in the hypothesis model of this study is statistically significant with good fitness.

Table 5. Standardized path coefficient

\begin{tabular}{clcc}
\hline Hypothesis & Paths & Coefficient & Results \\
\hline H1 & Organizational learning $\rightarrow$ TQM & $0.882^{* * *}$ & Accept \\
H2 & TQM $\rightarrow$ business performance & $0.223^{*}$ & Accept \\
H3 & Organizational learning $\rightarrow$ business performance & $0.509^{* * *}$ & Accept \\
H4 & Organizational learning $\rightarrow$ TQM $\rightarrow$ business performance & $0.179^{*}$ & Accept \\
\hline
\end{tabular}

Note. *Significant at $\mathrm{P}<0.05$, ** Significant at $\mathrm{P}<0.01$, *** Significant at $\mathrm{P}<0.001$.

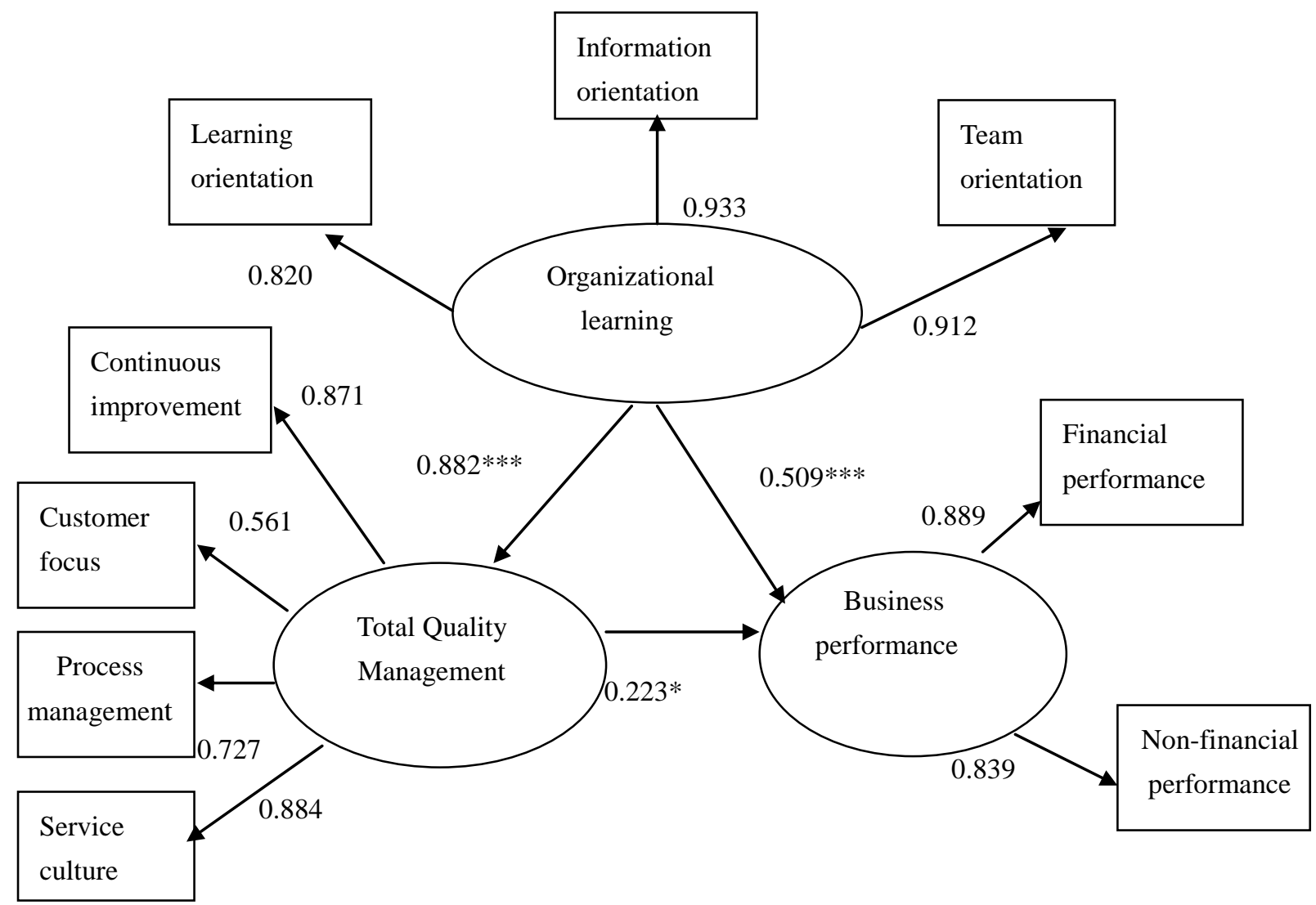

Figure 2. Path diagram for structural model

Note. *Significant at $\mathrm{P}<0.05$, ** Significant at $\mathrm{P}<0.01$, *** Significant at $\mathrm{P}<0.001$. 


\section{Conclusion and Managerial Implications}

Overall, the result of this study provides a more comprehensively theoretical and empirical foundation for understanding the integrated relationship among organizational learning, TQM and business performance. The findings also suggest that the effect of organizational learning on business performance is indirect through the success of TQM. This research is crucial if the researchers and business practitioners are to learn how the organization can effectively learn, adapt, and implement TQM in order to enhance insurer's performance and further apply to service industry and improve business development.

In practice, this research provides some practical insights into integrated relationship among organizational learning, TQM practices and business performance and extends the framework of business excellence in non-life insurance industry. First, organizational learning has a positive impact on TQM as proposed by Chiles and Choi (2000) and Koçoğlu et al. (2011), therefore, the managers can implement functional approach of learning project in practice to enhance the manager's duties and develop the concept of service quality to influence the implementation of the TQM in order to achieve the process improvement, deeply rooted in the service culture to meet the needs of the customer, and strengthen the company's competitive advantage. Second, the industries should encourage managers to design their organizations with shared open-minded approaches to problem solving, organizational culture and strategy that foster the learning, teamwork and other human resource management practices which encourage the creation of new knowledge (Fiol \& Lyles, 1985; Senge, 1990) in order to enhance firm's business performance. Third, the executives should look for the synergies between organizational learning and service quality assessment process in order to establish business excellence model and continuously assess customer satisfaction of existing and potential customers and enhance total quality service for effective improvement in overall business performance (Boulter et al., 2013). Finally, it will throw some light on several issues or at least pave the way to new research projects that consolidates the study of financial service industry's organizational learning, TQM and firm's business performance at an evidential level.

\section{References}

Agus, A. (2004). TQM as a focus for improving service performance and customer satisfaction: An empirical study on a public service sector in Malaysia. Total Quality Management \& Business Excellence, 15(4), 615-628. http://dx.doi.org/10.1080/14783360410001680107

Ahmad, M. H., Gutiérrez-Gutiérrez, L., \& Rosas, J. E. M. (2014). Total quality management practices, competitive strategies and financial performance: The case of the Palestinian industrial SMEs. Total Quality Management \& Business Excellence, 25(5-6), 635-649. http://dx.doi.org/10.1080/14783363.2013.824714

Bagozzi, R. P., \& Yi, Y. (1988). On the evaluation of structure equations model. Journal of Academic of Marketing Science, 16(1), 74-94. http://dx.doi.org/10.1007/BF02723327

Barrow, J. W. (1993). Does total quality management equal organizational learning? Quality Progress, 26(7), $39-43$.

Bartlett, M. S. (1950). Tests of significance of factor analysis. British Journal of Psychology (Statistical Section), 3(2), 77-85. http://dx.doi.org/10.1111/j.2044-8317.1950.tb00285.x

Bollen, K. A. (1989). Structural equations with latent variables. New York, NY: Wiley.

Bontis, N., Crossan, M., \& Hulland, J. (2002). Managing an organizational learning system by aligning stocks $\begin{array}{lllll}\text { and flows. Journal of } & \text { Management }\end{array}$ http://dx.doi.org/10.1111/1467-6486.t01-1-00299

Boulter, L., Bendel, T., \& Dahlgaard, J. J. (2013). Total quality beyond North America: A comparative analysis of the performance of European Excellence Award winners. International Journal of Operations and Production Management, 33(2), 197-215. http://dx.doi.org/10.1108/01443571311295635

Brah, S. A., Wong, J. L., \& Rao, B. M. (2000). TQM and business performance in the service sector: A Singapore study. International Journal of Operations and Production Management, 20(11), 1293-1312. http://dx.doi.org/10.1108/01443570010348262

Calantone, R. J., Cavusgi, S. T., \& Zhao, Y. (2002). Learning orientation, firm innovation capability, and firm $\begin{array}{llll}\text { performance. } \quad \text { Industrial } & \text { Marketing }\end{array}$ http://dx.doi.org/10.1016/S0019-8501(01)00203-6

Chang, S. H. (2008). Research Methodology: Theory and Statistics. Tsang Hai, Taichung.

Chiles, T., \& Choi, T. Y. (2000). Theorizing TQM: An Austrian and evolutionary economics interpretation. 
Journal of Management Studies, 37(2), 185-212. http://dx.doi.org/10.1111/1467-6486.00177

Corbett, C. J., Montes-Sancho, M. J., \& Kirsch, D. K. (2005). The financial impact of ISO 9000 certification in the United States: An empirical analysis. Management Science, 51(7), 1046-1059. http://dx.doi.org/10.1287/mnsc.1040.0358

Delaney, J. T., \& Huselid, M. A. (1996). The impact of human resource management practices on perceptions of organizational performance. Academy of Management Journal, 39(4), 949-969. http://dx.doi.org/10.2307/256718

Denton, J. (1998). Organizational learning and effectiveness. London: Routledge.

Dess \& Robinson. (1984). Measuring organizational performance in the absence of objective measures. Strategic Management Journal, 15(3), 265-273. http://dx.doi.org/10.1002/smj.4250050306

Ebrahimi, M., \& Sadeghi, M. (2013). Quality management and performance: An annotated review. International Journal of Production Research, 51(18), 5625-5643. http://dx.doi.org/10.1080/00207543.2013.793426

Fiol, C. M., \& Lyles, M. A. (1985). Organizational learning. Academy of Management Review, 10(4), 803-813. http://dx.doi.org/10.5465/AMR.1985.4279103

Flynn, B., Schroeder, R., \& Sakakibara, S. (1995). The impact of quality management practices on performance $\begin{array}{llll}\text { and competitive } & \text { advantage. Decision }\end{array}$ http://dx.doi.org/10.1111/j.1540-5915.1995.tb01445.x

Fotopoulos, C. V., \& Psomas, E. L. (2010). The structural relationships between TQM factors and organizational performance. The TQM Journal, 22(5), 539-552. http://dx.doi.org/10.1108/17542731011072874

Hair, J. F., Anderson, R. E., Tatham, R. L., \& Black, W. C. (1998). Multivariate data analysis. New Jersey: Prentice-Hall.

Hair, J. F., Black,W. C., Babin, B. J., Anderson, R. E., \& Tatham, R. L. (2006). Multivariate data analysis (6th ed.). Englewood Cliffs, Prentice-Hall International, New Jersey.

Hao, Q., Kasper, H., \& Muehlbacher, J. (2012). How does organizational structure influence performance through learning and innovation in Austria and China. Chinese Management Studies, 6(1), 36-52. http://dx.doi.org/10.1108/17506141211213717

Hendticks, K. B., \& Singhal, V. R. (1997). Does implementing an effective TQM program actually improve operating performance? Empirical evidence from firms that have won quality awards. Management Science, 43(9), 1258-1274. http://dx.doi.org/10.1287/mnsc.43.9.1258

Honarpour, A., \& Asadi, A. (2012). TQM and organizational learning: A methodological perspective. International Journal of Business and Management Tomorrow, 2(9), 1-6. http://dx.doi.org/10.1080/14783363.2013.824714

Huber, G. (1991). Organizational learning: The contributing processes and the literatures. Organization Science, 2(1), 88-115. http://dx.doi.org/10.1287/orsc.2.1.88

Hult, G. T. M., \& Ferrel, O. C. (1997). Global organizational learning capacity in purchasing: Construct and measurement. Journal of Business Research, 40, 97-111. http://dx.doi.org/10.1016/S0148-2963(96)00232-9

Hult, G. T. M., Ferrell, O. C., \& Hurley, R. F. (2002). Global organizational learning effects on cycle time $\begin{array}{llll}\text { performance. Journal of Business } & \text { Research, }\end{array}$ http://dx.doi.org/10.1016/S0148-2963(00)00161-2

Hung, R. Y. Y., Lien, B. H., Yang, B. Y., Wu, C. M., \& Kuo, Y. M. (2011). Impact of TQM and organizational learning on innovation performance in the high-tech industry. International Business Review, 20, 213-225. http://dx.doi.org/10.1016/j.ibusrev.2010.07.001

Hurley, R. F., \& Hult, G. (1998). Innovation, market orientation and organizational learning: An integrative with empirical investigation. Journal of Marketing, 62(3), 42-54. http://dx.doi.org/10.2307/1251742

Irani, Z., Beskese, A., \& Love, P. (2004). Total quality management and corporate culture: Constructs of organizational excellence. Technovation, 24, 643-650. http://dx.doi.org/10.1016/S0166-4972(02)00128-1

Issac, G., Rajendran, C., \& Anantharaman, R. N. (2004). Significance of quality certification: The case of the Software Industry in India. The Quality Management Journal, 11(1), 8-32.

Juran, J. M. (1993). Made in USA: A renaissance in quality. Harvard Business Review, 71(4), 42-50. 
Kaiser, H. F. (1974). An index of factorial simplicity. Psychometrika, 39, 31-36. http://dx.doi.org/10.1007/BF02291575

Kaynak, H. (2003). The relationship between total quality management practice and their effects on firm performance. Journal of Operation Management, 21, 405-435. http://dx.doi.org/10.1016/S0272-6963(03)00004-4

Koçoğlu, İ., İmamoğlu, S. Z., \& İnce, H. (2011). The relationship between organizational learning and firm performance: The mediating roles of innovation and TQM. Journal of Global Strategic Management, 9, 72-88.

Lam, S. Y., Lee, V. H., Ooi, K. B., \& Lin, B. (2011). The relationship between TQM, learning orientation and market performance in service organizations: an empirical analysis. Total Quality Management \& Business Excellence, 22(12), 1277-1297. http://dx.doi.org/10.1080/14783363.2011.631337

Lee, V. H., Lam, S. Y., Ooi, K. B., \& Safa, M. S. (2010). Structural analysis of TQM and its impact on customer satisfaction and innovation. International Journal of Modeling in Operations Management, 1(2), 157-179. http://dx.doi.org/10.1504/IJMOM.2010.038147

Leonard, D., \& McAdam, R. (2003). Impacting organizational learning: The training and experiences of quality award examiners and assessors. Journal of European Industrial Training, 27(1), 16-21. http://dx.doi.org/10.1108/03090590310456492

Li, Y., Wang, L., \& Liu, Y. (2011). Organizational learning, product quality and performance: The moderating effect of social ties in Chinese cross-border outsourcing. International Journal of Production Research, 49(1), 159-182. http://dx.doi.org/10.1080/00207543.2010.508943

Li-tze, H., \& Bentler, P. (1999). Cutoff criteria for fit indexes in covariance structure analysis: Conventional criteria versus new alternatives. Structural Equation Modeling, 6(1), 1-55. http://dx.doi.org/10.1080/10705519909540118

Luksa, B. A., Hult, G. T. M., \& Ferrel, O. C. (1996). A theoretical perspective of antecedents and Consequences of organizational learning in marketing channels. Journal of Business Research, 36(3), 233-244. http://dx.doi.org/10.1016/0148-2963(95)00154-9

Martinez-Costa, M., \& Jimenez-Jimenez, D. (2009). The effectiveness of TQM: The key role of organizational learning in small business. International Small Business Journal, 27, 98-125. http://dx.doi.org/10.1177/0266242608098348

Meso, P. M., Troutt, M. D., \& Rudnicka, J. (2002). A revise of naturalistic decision making research with some implications for knowledge management. Journal of Knowledge Management, 6(1), 63-73. http://dx.doi.org/10.1108/13673270210417709

Moreno, A. R., Fernandez, L. M. M., \& Montes, F. J. L. (2009). The moderating effect of slack resources on the relation between quality management and organizational learning. International Journal of Production Research, 47(19), 5501-5523. http://dx.doi.org/10.1080/00207540802014692

Noruzy, A., Dalfard, V. M., Azhdari, B., Nazari-Shirkouhi, S., \& Rezazadeh. (2013). Relation between transformational leadership, organizational learning, knowledge management, organizational innovation and organizational performance: An empirical investigation of manufacturing firms. The International Journal of Advanced Manufacturing Technology, 64(5-8), 1073-1085. http://dx.doi.org/10.1007/s00170-012-4038-y

Nunnally, J. (1978). Psychometric theory (2nd ed.). New York, NY: McGraw-Hill.

O’Dell, C., \& Grayson, J. (1998). If only we knew what we know: Identification and transfer of internal best practices. California Management Review, 40(3), 154-174. http://dx.doi.org/10.2307/41165948

Oakland, J. (2005). From quality to excellence in the $21^{\text {st }}$ century. Total Quality Management, 16(8-9), 1053-1060. http://dx.doi.org/10.1080/14783360500163268

Phan, A. C., Abdallah, A. B., \& Matsui, Y. (2011). Quality management practices and competitive performance: Empirical evidence from Japanese manufacturing companies. International Journal of Production Economics, 133(2), 518-529. http://dx.doi.org/10.1016/j.ijpe.2011.01.024

Podsakoff, P. M., MacKenzie. S. B., Lee, J. Y., \& Podsakoff, N. P. (2003). Common method biases in behavioral research: A critical review of the literature and recommended remedies. Journal of Applied Psychology, 88(5), 879-903. http://dx.doi.org/10.1037/0021-9010.88.5.879 
Powell, T. C. (1995). Total quality management as competitive advantage: A review and empirical study. Strategic Management Journal, 6(1), 15-27. http://dx.doi.org/10.1002/smj.4250160105

Prajogo, D., \& Brown, A. (2004). The relationship between TQM practices and quality performance and the role of formal TQM programs: An Australian empirical study. Quality Management Journal, 11(4), 31-42.

Sadikoglu \& Olcay. (2014). The effects of total quality management practices on performance and the reasons of and the barriers to TQM practices in Turkey. Advances in Decision Sciences, 1-17. http://dx.doi.org/10.1155/2014/537605

Salaheldin, S. I. (2009). Critical success factors for TQM implementation and their impact on performance of SMEs. International Journal of Productivity and Performance Management, 58(3), 215-237. http://dx.doi.org/10.1108/17410400910938832

Samat, N., Ramayah, T., \& Saad, N. M. (2006). TQM practices, service quality, and market orientation-some empirical evidence from a developing country. Management Research News, 29(11), 713-728. http://dx.doi.org/10.1108/01409170610716025

Santos-Vijande, M. L., López-Sánche, J. Á., \& Trespalacios, J. A. (2012). How organizational learning affects a firm's flexibility, competitive strategy and performance. Journal of Business Research, 65(8), 1079-1089. http://dx.doi.org/doi:10.1016/j.jbusres.2011.09.002

Schumacker, R. E., \& Lomax, R. G. (2004). A Beginner's guide to structural equation modeling (2nd ed.). Lawrence Erlbaum Associates, Mahwah, NJ.

Selvaraj, M. (2009). Total quality management in Indian commercial banks: A comparative study. Journal of Marketing \& Communication, 4(3), 59-70.

Senge, P. (1990). The fifth discipline: The art and practice of the learning organization. Doubleday, New York, NY.

Slater, S. F., \& Narver, J. C. (1995). Market orientation and the learning organization. Journal of Marketing, 59(3), 63-74. http://dx.doi.org/10.2307/1252120

Slia, I., \& Ebrahimpour, M. (2005). Critical linkages among TQM factors and business result. International Journal of Operations \& Production Management, 25(11), 1123-1155. http://dx.doi.org/10.1108/01443570510626925

Sohal, A., \& Morrison, M. (1995). Is there a link between total quality management and learning organizations? TQM Magazine, 7(3), 41-44. http://dx.doi.org/10.1108/09544789510087751

Spanos, Y. E., \& Lioukas, S. (2001). An examination into the causal logic of rent generation: Contrasting Porter's competitive strategy framework and the resource-based perspective. Strategic Management Journal, 22(10), 907-934. http://dx.doi.org/10.1002/smj.174

Sureshchandar, G. S., Rajendran, C., \& Anantharaman, R. N. (2001). A conceptual model for total quality management in service organizations. Total Quality Management \& Business Excellence, 12(3), 343-363. http://dx.doi.org/10.1080/09544120120034492

The Non-insurance Association of R.O.C. (2013). 2013 fact book non-life insurance business in Taiwan. The non-insurance association of R.O.C., Taipei.

Tippins, M. J., \& Sohi, R. S. (2003). IT competency and firm performance: Is organizational learning a missing link? Strategic Management Journal, 24(8), 745-761. http://dx.doi.org/10.1002/smj.337

Tsang, J. H. Y., \& Antony, J. (2001). Total quality management in UK service organizations: Some key findings from a survey? Managing Service Quality, 11(2), 132-141. http://dx.doi.org/10.1108/09604520110387293

Ullman, J. B. (2007). Structural equation modeling. In B. G. Tabachnick, \& L. S. Fidell (Eds.), Using multivariate statistics (pp. 676-780). Boston, MA: Pearson Education.

Venkatraman, N., \& Ramanujam, V. (1986). Measurement of business performance in strategy research: A comparison of approaches. Academy of Management Review, 11(4), 801-814. Retrieved from http://www.jstor.org/stable/258398

Wali, S., \& Boujelbene, Y. (2010). The effect of TQM implementation on firm performance in the Tunisian context. International Journal of Productivity and Quality Management, 5(1), 60-74. http://dx.doi.org/10.1504/IJPQM.2010.029510

Wang, C. H., Chen, K. Y., \& Chen, S. C. (2012). Total quality management, market orientation and hotel 
performance: The moderating effects of external environmental factors. International Journal of Hospitality Management, 31, 119-129. http://dx.doi.org/doi:10.1016/j.ijhm.2011.03.013

Wiengarten, F., Fynes, B., Cheng, E. T. C., \& Chavez, R. (2013). Taking an innovative approach to quality practices: Exploring the importance of a company's innovativeness on the success of TQM practices. $\begin{array}{lllll}\text { International Journal of Production } & \text { Research, }\end{array}$ http://dx.doi.org/10.1080/00207543.2012.752609

Yang, C., Wang, Y. D., \& Niu, H. J. (2007). Does industry matter in attributing organizational learning to its performance? Evidence from the Taiwanese economy. Asia Pacific Business Review, 13(4), 547-563. http://dx.doi.org/10.1080/13602380701376767

\section{Copyrights}

Copyright for this article is retained by the author(s), with first publication rights granted to the journal.

This is an open-access article distributed under the terms and conditions of the Creative Commons Attribution license (http://creativecommons.org/licenses/by/3.0/). 